\title{
CONTENTS
}

\section{Volume 46 Number 1}

\section{Research Papers}

1 F. THOMAS BRUSS AND YVIK C. SWAN. A continuous-time approach to Robbins' problem of minimizing the expected rank

19 NEERAJ MISRA, ISHWARI D. DHARIYAL AND NITIN GUPTA. Optimal allocation of active spares in series systems and comparison of component and system redundancies

35 DAVID HARTVIGSEN. The action gambler and equal-sized wagering

55 JAIME A. LONDOÑO. State-dependent utility

71 YU-TING CHEN, CHENG-FEW LEE AND YUAN-CHUNG SHEU. An integral-equation approach for defaultable bond prices with application to credit spreads

85 R. L. LOEFFEN. An optimal dividends problem with a terminal value for spectrally negative Lévy processes with a completely monotone jump density

99 MAIKOL A. DIASPARRA AND ROSARIO ROMERA. Bounds for the ruin probability of a discrete-time risk process

113 ANDREI L. BADESCU, ERIC C. K. CHEUNG AND DAVID LANDRIAULT. Dependent risk models with bivariate phase-type distributions

132 OLE E. BARNDORFF-NIELSEN, JOSÉ MANUEL CORCUERA, MARK PODOLSKIJ AND JEANNETTE H. C. WOERNER. Bipower variation for Gaussian processes with stationary increments

151 BERNARD BERCU, PEGGY CÉNAC AND GUY FAYOLLE. On the almost sure central limit theorem for vector martingales: convergence of moments and statistical applications

170 ERIK EKSTRÖM AND HENRIK WANNTORP. Optimal stopping of a Brownian bridge

181 T. R. HURD AND A. KUZNETSOV. On the first passage time for Brownian motion subordinated by a Lévy process

199 M. DRAIEF, A. GANESH AND L. MASSOULIÉ. Exponential random graphs as models of overlay networks

221 FUBAO XI AND G. YIN. Asymptotic properties of a mean-field model with a continuous-statedependent switching process

244 YAMING YU. Stochastic ordering of exponential family distributions and their mixtures

255 TASOS C. CHRISTOFIDES AND EUTICHIA VAGGELATOU. Bounds for the distance between the distributions of sums of absolutely continuous i.i.d. convex-ordered random variables with applications

272 P. VELLAISAMY AND N. S. UPADHYE. On the sums of compound negative binomial and gamma random variables

284 TOSHIO NAKATA. Necklace processes via Pólya urns

296 DOMINIK HEINZMANN. Extinction times in multitype Markov branching processes 


\section{Volume 46 Number 2}

\section{Research Papers}

309 WOJCIECH NIEMIRO AND PIOTR POKAROWSKI. Fixed precision MCMC estimation by median of products of averages

330 TERJE AVEN. Optimal test interval for a monotone safety system

342 SUBHASH KOCHAR AND MAOCHAO XU. Comparisons of parallel systems according to the convex transform order

353 JI HWAN CHA AND MAXIM FINKELSTEIN. On a terminating shock process with independent wear increments

363 OFFER KELLA. On growth-collapse processes with stationary structure and their shot-noise counterparts

372 HÉCTOR JASSO-FUENTES AND ONÉSIMO HERNÁNDEZ-LERMA. Blackwell optimality for controlled diffusion processes

392 FANG XU. A central limit theorem associated with the transformed two-parameter PoissonDirichlet distribution

402 AIKO KURUSHIMA AND KATSUNORI ANO. Maximizing the expected duration of owning a relatively best object in a Poisson process with rankable observations

415 ANNA KARPOWICZ. Double optimal stopping in the fishing problem

429 AGNĖS LAGNOUX-RENAUDIE. A two-step branching splitting model under cost constraint for rare event analysis

453 YUQIANG LI. A weak limit theorem for generalized Jiřina processes

463 DANIELA BERTACCHI AND FABIO ZUCCA. Approximating critical parameters of branching random walks

479 RONG-LI LIU, YAN-XIA REN AND RENMING SONG. $L \log L$ criterion for a class of superdiffusions

497 V. B. YAP. Similar states in continuous-time Markov chains

507 JOHAN S. H. VAN LEEUWAARDEN, MARK S. SQUILLANTE AND ERIK M. M. WINANDS. Quasi-birth-and-death processes, lattice path counting, and hypergeometric functions

521 ERIC C. K. CHEUNG AND DAVID LANDRIAULT. Perturbed MAP risk models with dividend barrier strategies

542 E. J. BAURDOUX. Last exit before an exponential time for spectrally negative Lévy processes

559 XUEMIAO HAO, QIHE TANG AND LI WEI. On the maximum exceedance of a sequence of random variables over a renewal threshold

571 ARUP BOSE, AMITES DASGUPTA AND KRISHANU MAULIK. Strong laws for balanced triangular urns

\section{Short Communications}

585 ANNA PÓSFAI. Poisson approximation in a Poisson limit theorem inspired by coupon collecting

593 SVANTE JANSON AND NICLAS PETERSSON. The integral of the supremum process of Brownian motion

601 THOMAS M. LIGGETT AND RINALDO B. SCHINAZI. A stochastic model for phylogenetic trees 
Volume 46 Number 3

Research Papers

609 CHRISTIAN BENDER AND TINA MARQUARDT. Integrating volatility clustering into exponential Lévy models

629 MICHAEL R. TEHRANCHI. Asymptotics of implied volatility far from maturity

651 S. C. P. YAM, S. P. YUNG AND W. ZHOU. Two rationales behind the 'buy-and-hold or sellat-once' strategy

669 ETIENNE PARDOUX AND MAJID SALAMAT. On the height and length of the ancestral recombination graph

690 SANDA N. SOCOLL AND A. D. BARBOUR. Local limit approximations for Markov population processes

709 XIAOYU XING, WEI ZHANG AND YONGJIN WANG. The stationary distributions of two classes of reflected Ornstein-Uhlenbeck processes

721 SHIBIN ZHANG AND XINSHENG ZHANG. On the transition law of tempered stable Ornstein-Uhlenbeck processes

732 SHAI COVO. On approximations of small jumps of subordinators with particular emphasis on a Dickman-type limit

756 SERGEY FOSS, DMITRY KORSHUNOV AND STAN ZACHARY. Convolutions of longtailed and subexponential distributions

768 SØREN ASMUSSEN. Importance sampling for failure probabilities in computing and data transmission

791 ROMUALD ELIE. Double kernel estimation of sensitivities

812 SAUL JACKA. Markov chains conditioned never to wait too long at the origin

827 RAFIK AGUECH. Limit theorems for random triangular urn schemes

844 CHARLES BORDENAVE, SERGUEI FOSS AND VSEVOLOD SHNEER. A random multipleaccess protocol with spatial interactions

866 THIERRY HUILLET AND MARTIN MÖHLE. Duality and asymptotics for a class of nonneutral discrete Moran models

894 KRZYSZTOF JASIŃSKI, JORGE NAVARRO AND TOMASZ RYCHLIK. Bounds on variances of lifetimes of coherent and mixed systems

\section{Short Communications}

909 GWO DONG LIN AND JORDAN STOYANOV. The logarithmic skew-normal distributions are moment-indeterminate

917 DIDIER PIAU. Asymptotics of iterated branching processes 
Volume 46 Number 4

\section{Research Papers}

925 HAIJUN LI AND YANNAN SUN. Tail dependence for heavy-tailed scale mixtures of multivariate distributions

938 JEAN-FRANÇOIS DELMAS AND BENJAMIN JOURDAIN. Does waste recycling really improve the multi-proposal Metropolis-Hastings algorithm? An analysis based on control variates

960 F. MENDIVIL, R. SHONKWILER AND M. C. SPRUILL. Geometric convergence of genetic algorithms under tempered random restart

975 TOM BRITTON AND MATHIAS LINDHOLM. The early stage behaviour of a stochastic SIR epidemic with term-time forcing

993 S. MA AND M. MOLINA. Two-sex branching processes with offspring and mating in a random environment

1005 MIKLÓS BÓNA AND PHILIPPE FLAJOLET. Isomorphism and symmetries in random phylogenetic trees

1020 SARAH BEHRENS AND MATTHIAS LÖWE. Moderate deviations for word counts in biological sequences

1038 RUDOLF GRÜBEL AND PAWEł HITCZENKO. Gaps in discrete random samples

1052 M. BURKSCHAT. Systems with failure-dependent lifetimes of components

1073 EROL A. PEKÖZ, ADRIAN RÖLLIN, VYDAS ČEKANAVIČIUS AND MICHAEL SHWARTZ. A three-parameter binomial approximation

1086 MITSUSHI TAMAKI. Optimal choice of the best available applicant in full-information models

1100 BORIS BAEUMER, MARK M. MEERSCHAERT AND ERKAN NANE. Space-time duality for fractional diffusion

1116 DAVID APPLEBAUM AND MICHAILINA SIAKALLI. Asymptotic stability of stochastic differential equations driven by Lévy noise

1130 G. DELIGIANNIDIS, H. LE AND S. UTEV. Optimal stopping for processes with independent increments, and applications

1146 ANDREAS E. KYPRIANOU AND XIAOWEN ZHOU. General tax structures and the Lévy insurance risk model

1157 O. L. V. COSTA AND F. DUFOUR. The vanishing discount approach for the average continuous control of piecewise deterministic Markov processes

1184 C. F. COLETTI, L. R. G. FONTES AND E. S. DIAS. Scaling limit for a drainage network model

\section{Short Communications}

1198 KENSHI HOSAKA. An alternative condition for stochastic domination

1201 LARS HOLST. On consecutive records in certain Bernoulli sequences

1209 EUGENE A. FEINBERG AND JUN FEI. An inequality for variances of the discounted rewards

1213 XIAN-YUAN WU, ZHAO DONG, KE LIU AND KAI-YUAN CAI. On the degree sequence of an evolving random graph process and its critical phenomenon

\section{Letter to the Editor}

1221 QI ZHENG. Remarks on the asymptotics of the Luria-Delbrück and related distributions

1225 Index 


\section{Subscription rates}

Subscription rates for volume 46 (2009) of Journal of Applied Probability (JAP) are as follows (post free and including online access at http://projecteuclid.org/jap/): US\$384.00; A $\$ 402.00 ; £ 186.00$ for libraries and institutions; or US\$128.00; A $\$ 134.00$; $£ 62.00$ for individuals belonging to a recognised scientific society. The subscription rates for volume 41 (2009) of Advances in Applied Probability, the companion publication, are the same; if both journals are ordered directly from the Applied Probability office at the same time, the combined price is discounted by $10 \%$. Please send all enquiries to: Applied Probability Subscriptions, School of Mathematics and Statistics, University of Sheffield, Sheffield S3 7RH, UK (telephone +44 114222 3922; fax +44114272 9782; email s.c.boyles@ sheffield.ac.uk). Cheques, money orders, etc. should be made payable to 'Applied Probability'. Payment is acceptable in US, Australian or UK currency, or by Visa or Mastercard. We can provide back issue prices on application.

\section{Notes for contributors}

Research papers are published in both Journal of Applied Probability (JAP) and Advances in Applied Probability ( $A A P$ ), with longer papers typically appearing in $A A P$. However, assignation of papers between the two journals is made by the Editor on an issue-by-issue basis. A submission to Applied Probability is considered as a submission to either journal. In addition, JAP publishes short communications of a few printed pages in the nature of notes and letters specifically related to papers that have appeared in JAP. Review papers and papers in stochastic geometry and statistical applications are published in AAP.

Fifty offprints of each paper will be provided free, with additional offprints available at cost.

Papers submitted to the Applied Probability journals are considered on the understanding that they have not been published previously and are not under consideration by another publication. Accepted papers will not be published elsewhere without the written permission of the Trust. Submitted papers should be in English. It is the author's responsibility to ensure an acceptable standard of language, and a paper failing to meet this requirement may go back to the author for rewriting before being sent out for review.

Papers should include: (i) a short abstract of 4-10 lines giving a non-mathematical description of the subject matter and results; (ii) a list of keywords detailing the contents; and (iii) a list of classifications, using the 2000 Mathematics Subject Classification scheme (http://www.ams.org/msc/). Letters to the Editor need not include these. To assist authors in writing papers in the Applied Probability style, they may use the IATEX class file aptpub.cls, available from http://www.appliedprobability.org/. Use of this class file is not a condition of submission, but will considerably increase the speed at which papers are processed.

Papers should be submitted as hard copy or as electronic files (with hard copy back-up). All submissions will be acknowledged on receipt and must be accompanied by a covering letter stating the author's postal address and affiliation. Hard copy: Send all submissions to the Applied Probability office in Sheffield, and not to individual editors. Two copies of the paper, at least one of which should be double spaced, should be sent to: Executive Editor, Applied Probability, School of Mathematics and Statistics, University of Sheffield, Sheffield S3 7RH, UK. Electronic submission: Please email a double-spaced PostScript ${ }^{\mathrm{TM}}$ (.ps) or portable document format (.pdf) file, not exceeding $1 \mathrm{Mb}$. The files must be clearly identified by name in a separate covering message. The address for email submissions is I.nash@sheffield.ac.uk. Authors should also submit one hard copy to the Executive Editor, as above.

\section{Copyright}

The copyright of all published papers is vested in the Applied Probability Trust. When a paper is accepted for publication, the Trust asks the authors to assign copyright by signing a form in which the terms of copyright are listed. Failure to do this promptly may delay or prevent publication.

Authorisation to photocopy items for internal or personal use, or the internal or personal use of specific clients, is granted by the Applied Probability Trust for libraries and other users registered with the Copyright Clearance Center (CCC) Transactional Reporting Service, provided that the corresponding processing and royalty fees (see http://www.copyright.com) are paid directly to CCC, 222 Rosewood Drive, Danvers, MA 01923, USA. 0021-9002/09 


\section{Volume 46 Number 4}

Research Papers

925 HAIJUN LI AND YANNAN SUN. Tail dependence for heavy-tailed scale mixtures of multivariate distributions

938 JEAN-FRANÇOIS DELMAS AND BENJAMIN JOURDAIN. Does waste recycling really improve the multi-proposal Metropolis-Hastings algorithm? An analysis based on control variates

960 F. MENDIVIL, R. SHONKWILER AND M. C. SPRUILL. Geometric convergence of genetic algorithms under tempered random restart

975 TOM BRITTON AND MATHIAS LINDHOLM. The early stage behaviour of a stochastic SIR epidemic with term-time forcing

993 S. MA AND M. MOLINA. Two-sex branching processes with offspring and mating in a random environment

1005 MIKLÓS BÓNA AND PHILIPPE FLAJOLET. Isomorphism and symmetries in random phylogenetic trees

1020 SARAH BEHRENS AND MATTHIAS LÖWE. Moderate deviations for word counts in biological sequences

1038 RUDOLF GRÜBEL AND PAWEł HITCZENKO. Gaps in discrete random samples

1052 M. BURKSCHAT. Systems with failure-dependent lifetimes of components

1073 EROL A. PEKÖZ, ADRIAN RÖLLIN, VYDAS ČEKANAVIČIUS AND MICHAEL SHWARTZ. A three-parameter binomial approximation

1086 MITSUSHI TAMAKI. Optimal choice of the best available applicant in full-information models

1100 BORIS BAEUMER, MARK M. MEERSCHAERT AND ERKAN NANE. Space-time duality for fractional diffusion

1116 DAVID APPLEBAUM AND MICHAILINA SIAKALLI. Asymptotic stability of stochastic differential equations driven by Lévy noise

1130 G. DELIGIANNIDIS, H. LE AND S. UTEV. Optimal stopping for processes with independent increments, and applications

1146 ANDREAS E. KYPRIANOU AND XIAOWEN ZHOU. General tax structures and the Lévy insurance risk model

1157 O. L. V. COSTA AND F. DUFOUR. The vanishing discount approach for the average continuous control of piecewise deterministic Markov processes

1184 C. F. COLETTI, L. R. G. FONTES AND E. S. DIAS. Scaling limit for a drainage network model

\section{Short Communications}

1198 KENSHI HOSAKA. An alternative condition for stochastic domination

1201 LARS HOLST. On consecutive records in certain Bernoulli sequences

1209 EUGENE A. FEINBERG AND JUN FEI. An inequality for variances of the discounted rewards

1213 XIAN-YUAN WU, ZHAO DONG, KE LIU AND KAI-YUAN CAI. On the degree sequence of an evolving random graph process and its critical phenomenon

\section{Letter to the Editor}

1221 QI ZHENG. Remarks on the asymptotics of the Luria-Delbrück and related distributions

1225 Index 